\title{
Costumes Unearthed from Vault 5 of Munchaktepa in the North of Ferghana Valley of Uzbekistan
}

\author{
Fang Wan \\ Fashion Institute of Design, Donghua University \\ Shanghai 200051, China \\ E-mail: wanfang1978@163.com
}

\begin{abstract}
Munchaktepa burial is an ancient Cemetery and belongs to 4 to 7 century which is located in Ferghana Valley. Local archaeologist has found some textile and garment in Munchaktepa burial since 1987 that is very rare in Central Asian. This article mainly introduces the location and age of the Munchaktepa burial, and the type and style of garment accessories which unearthed from Munchaktepa. In addition, Author released her study of reconstruction on the style of some important kind of garment.
\end{abstract}

Keywords: Munchaktepa, Uzbekistan, Textile, Garment, Reconstruction

\section{Background of the Munchaktepa burial}

\subsection{Location and age of the Munchaktepa burial}

The Munchaktepa burial ground is located 2-3km to the South from Pap city (Namangan province, Uzbekistan) on the right-bank of Syr-Darya in Ferghana Valley. Since 1987 B.Kh. Matbabaev has been carrying out archaeological works in that area. (Note 1) During this working period, 1987-1993, the following types of burial constructions were revealed at the burial ground: single grave (pit graves and niche graves) at Munchaktepa I, vault graves at Munchaktepa II.

According to archaeologists study, there are two phases of the burial ground in Munchaktepa. The early phase of burials is between 5-6th centuries, materials of this phase were discovered from vaults 1, 5, sections and sondages of Munchaktepa II. They are dated back to earlier period, than the rest complex of burial ground.

Materials of the second phases were discovered in small vaults 2, 3 and 4 and in large vault 9 . The previous $\left(5-6^{\text {th }}\right.$ centuries) way of development of pottery production remained in this complex. At the same time deterioration of ceramic quality is observed. E.g., washed or partly peeling slip or pottery without slip at all was met. Ceramics with scratched decoration disappeared at the end of period. Some shapes decorated with painted ornamentation and raised border with incisions were revealed.

\subsection{Discovery of fabrics from vault 5 of Munchaktepa}

Fabric remains were founded in vault 5, vaults 1, 3 and 9, all of these vaults are belong the early phase of burials. The number of fabric from vault 5 is 27 which is accounting for the vast majority of total. Cotton and silk are the mainly types fabrics in Munchaktepa.

The silk textiles excavated from vault 5 of Munchaktepa are mainly in silk tabby, but there are other varieties as well, including taquete in spun silk, taquete in flat silk, silk samite, and damask. Among them, the large quantities of textiles in silk tabby and damask that are technically simple should have been imported from China. Such material evidence demonstrates the influence of Chinese silks to silk productions elsewhere along the Silk Road. It is obvious that the taquete in flat silk and silk samite were produced in the Sogdian area of Uzbekistan, and then exported to China via the Silk Road. However, the taquete in spun silk was most probably woven in an area between the northwest of China and the Ferghana Valley to the east of Uzbekistan.

\subsection{Related research on costume from vault 5 of Munchaktepa}

Find of cloth remains is rare in archaeological practice. Data on Ferghana clothes in given period was very limited until the discovery of Munchaktepa burial ground. Information about clothes was mainly hypothetical, although there were 
finds of some fragments of fabric. That is why finds from the burial ground are very important in researches of Ferghana clothes.

Researches revealed that clothes in burials were not funereal. Ferghana population buried their dead in daily clothes, evidence of which is common stains, patch on dress skirt and worn multi-colored clothes due to long-term use. (Note 2)

For the first time the reconstruction of clothes was carried out by G. Maytdinova. During restoration and conservation of fabric she together with A.K. El'kina recorded data on dress-making. (Note 3) However, she did not pay much attention on classification and clipping of costume. We re-measurement and research the costume and textile from Munchaktepa in September 2008. Following is a summary of research findings.

\section{The type and style of garment accessories from Munchaktepa}

The discovered fabric is remains of clothes, face cover, head-dresses. The main part of clothes was made of fabric dyed with greyish black paint. Indigo was also used as dyeing material.

\subsection{Face cover}

Faces of some dead were covered with special veil made of thin silk of high quality. Faces of some dead were covered with special veil made of thin silk of high quality. For example, B-5-1 is a piece of face cover. (Figure 1)

With brown heavy silk tabby (B-5-1a) as the centre panel, edged with brown silk tabby (B-5-1b). The panel is $31 \mathrm{~cm}$ long and $47 \mathrm{~cm}$ wide. The width of the silk edge range from 1.8 and $3.5 \mathrm{~cm}$ already disintegrated into a few lengths. B-5-1c is ties for the face cover, made of brown silk $1.8 \mathrm{~cm}$ wide. Based on the form of the knotting, there were originally two pieces, each $45 \mathrm{~cm}$ in length. (Figure 2)

There is another face cover founded in coffin c-8. It is a damask with lozenge pattern (C-8-1). According to the excavation staff, it was found covering the face, from which it was inferred as the face covering. It has disintegrated into 8 fragments. Its original size is $40 \mathrm{~cm}$ in length and $25 \mathrm{~cm}$ in width.

\subsection{Head-dress}

Silk frontlets $4-6 \mathrm{~cm}$ wide and $40 \mathrm{~cm}$ long were founded in some burials. Silk frontlet similar in shape was found in barrow 10 of Kenkol burial ground. (Note 4) Frontlets were also revealed in Ferghana burial grounds of early $1^{\text {st }}$ millennium CE. The analogue shape of head-dress in many areas of Central Asia was ascertained by ethnographers. (Note 5)

Among materials from Munchaktepa there is one more type of head-dress. It was disclosed as large silk pieces placed under heads and around ears. Taking into account ethnographic data we assume that it can be remains of kerchief-shaped head-dress. Such frontlets are called "peshonaband" and worn by young ladies and brides also like kerchief as universal head-dress. Kerchiefs and frontlets were frequently combined. Other types of head-dresses were not preserved, but beads were found around head in some burials.

\subsection{Upper Garment}

The garments unearthed in Tomb No. 5 are basically in the style of pull-over tunics, which has three parts: bodice, neck trim and sleeves. The pull-over tunic has no full length opening at the front bodice, the garment is worn by pulling the neck opening over the head.

Usually an uncut length of cloth for the front and back, folded in half lengthwise to sit on the shoulders. Neck opening cut at the centre, then attach sleeves or edging, This basic form appear in different nations and cultures, with differences in details and embellishments. At Tomb No. 5 of Munchaktepa, 2 methods of cutting are discovered.

\subsubsection{Cutting Method I}

Analysis of the cutting method I is based on D-6 (Figure 3). The fabrics excavated from this coffin are rather intact as a finished garment. Upon their excavation, they have been taken care of by the conservators. All the textiles have been tacked on grey linen for support. D-6-1, a light brown tunic, is well preserved. The front and back is made in one rectangular panel (D-6-1a) shoulder and bottom edge both measure $51 \mathrm{~cm} .55 \mathrm{~cm}$ in length with neck opening in the centre. The neck opens $24.5 \mathrm{~cm}$ in depth and $8 \mathrm{~cm}$ in width. The left sleeve (D-6-1b) is intact, $25 \mathrm{~cm}$ in length, $26 \mathrm{~cm}$ wide at shoulder seam and $17 \mathrm{~cm}$ wide at the cuff. The right sleeve fragment (D-6-1C) is $21 \mathrm{~cm}$ in length, $26 \mathrm{~cm}$ wide at shoulder seam and $17 \mathrm{~cm}$ wide at cuff. D-6-2 is a wide outer neck facing, light brown, $36 \mathrm{~cm}$ in length, $17 \mathrm{~cm}$ wide at top section and $9 \mathrm{~cm}$ at bottom (Figure 4). D-6-3 to D-6-16 are all rectangular silk fragments with various lengths and widths. Some pieces have seam allowance at the edges.

The bodice and sleeves were all cut from a fabric $51 \mathrm{~cm}$ width. Neck opening cut in the centre (Figure 5), and facing cut from another piece. The body length is $55 \mathrm{~cm}$, the measurement sleeve cuff to sleeve cuff at shoulders measure less than $100 \mathrm{~cm}$, rather small size, may be made for a youngster. Its front and back view is illustrated in Figure 6.

\subsubsection{Cutting Method II}


Cutting Method I is relatively simple, but the width of the garments limited by the width of the woven cloth. Judging from the intact selvages, fabric widths are mostly $50-52 \mathrm{~cm}$ wide. When made up as garment in method I, the finished width will be around $50 \mathrm{~cm}$. To increase the width of the garment, method II is used, as shown in the fragments of L-2. (Figure 6, Figure 7 \& Figure 8)

Upper garment of silk, only part of the front bodice and sleeves are kept.

L-2-1a is the bodice panel, of $119 \mathrm{~cm}$ in length, bottom width $52 \mathrm{~cm}$. Neck opening in the centre, with a depth of about $30 \mathrm{~cm}$. On either sides of the bodice panel, are pieces trapezoid in shape, labeled as L-2-1b and L-2-1C.

L-2-1b measures $58 \mathrm{~cm}$ in length, top edge $5.5 \mathrm{~cm}$ in width and bottom $19 \mathrm{~cm}$.

$\mathrm{L}-2-1 \mathrm{c}$ is $35 \mathrm{~cm}$ in length, top edge $4 \mathrm{~cm}$ in width and bottom $12 \mathrm{~cm}$

$\mathrm{L}-2-1 \mathrm{~d}$ is $5.5 \mathrm{~cm}$ in length and $15 \mathrm{~cm}$ in width.

L-2-2 is the sleeve, the fragment is $58.5 \mathrm{~cm}$ in length, $57 \mathrm{~cm}$ in width. It three pieces sewn together.

L-2-2a is a square shape, fragment measures $49 \mathrm{~cm}$ in length, $50 \mathrm{~cm}$ in width, at both sides rectangular piece of silk is stitched .

L-2-2b is $9.5 \mathrm{~cm}$ in length, $50 \mathrm{~cm}$ in width.

L-2-2c is trapezoid in shape, $49 \mathrm{~cm}$ in length, with the upper and bottom width of $4.5 \mathrm{~cm}$ and $7 \mathrm{~cm} . \mathrm{L}-2-3$ is a sleeve panel, fragment $60 \mathrm{~cm}$ in length and $57 \mathrm{~cm}$ in width, it is also made of three pieces stitched together.

L2-3a is square shape, fragment $49 \mathrm{~cm}$ in length and $50.5 \mathrm{~cm}$ in width, at both sides rectangular piece of silk is stitched .

$\mathrm{L}-2-3 \mathrm{~b}$ is $9.5 \mathrm{~cm}$ in length and $51 \mathrm{~cm}$ in width.

L-2-3c is trapezoid in shape, $51 \mathrm{~cm}$ in length, with the upper and bottom width of $4 \mathrm{~cm}$ and $8 \mathrm{~cm}$. The reconstruction drawing and cutting arrangement as illustrated below.

The bodice of L-2 has been fragmented to several pieces. After reconstruction, we can tell the fragments of L-2-1a, and the above-mentioned D-6-1a were both made from an uncut piece of fabric. What makes them different is that at the sides of L-2-1a, there are the trapezoid pieces, i.e. L-2-1b and L-2-1C. In addition, there is another piece of remains L-2-1d at the sleeve seam, which is $5.5 \mathrm{~cm}$ in length and $15 \mathrm{~cm}$ in width. L-2-1b is in a better condition, with a right-angle indentation at the top, seam allowance and stitching marks (seen in Figure 2-13: partials of L-2-1b). Based on the comparison of the two sleeves of L-2- 2 and L-2-3, we can conclude that L-2-1b and L-2-1c was employed to increase the garment width and the right-angle indentation at the top part is for the setting in the sleeve.

With these details, we can infer the cutting method from the analysis of fragments from L-2, as displayed in Figure 9. The reconstruction drawing shows the garment is $110 \mathrm{~cm}$ in length and $117 \mathrm{~cm}$ sleeve cuff to cuff, through shoulder, $91 \mathrm{~cm}$ bottom width. Neck opening in the centre, with a neck depth around $30 \mathrm{~cm}$. Sleeve is $34 \mathrm{~cm}$ in width at armhole and $29 \mathrm{~cm}$ at the cuff.

\subsubsection{Neck Opening Type I (Inner Neck Facing)}

Type I is represented in B-3-1, C-6-1 and X-2.

B-3-1: The piece of B-3-1 is a brown collar facing, circular shape around the neck and pointed at chest, which we called as the inner neck facing made in the same style as that of C-6. Due to the damage at the upper part, it can be inferred that the original collar piece should be around $38 \mathrm{~cm}$ in length and $20 \mathrm{~cm}$ in width. The neck opening is $13 \mathrm{~cm}$ in depth and $10 \mathrm{~cm}$ in width. (Figure 10)

C-6-1: C-6-1 is a brown inner neck facing, 2 layers sewn together with a seam allowance of $0.8 \mathrm{~cm}$. The piece is $41 \mathrm{~cm}$ long, with a neck opening of $11.5 \mathrm{~cm}$ lengthwise, around $10 \mathrm{~cm}$ widthwise, with a $2.5 \mathrm{~cm}$ wide bottom edge(seen in Figure 2-5: Reconstruction Drawing of C-6-1). A piece of silk samite fragment is stitched to the bottom edge. (Figure 11)

According to the detail of B-3-1 and C-6-1, we believe that the shape of the neck opening facing is round on the top and tapers down to the bottom. The facing piece is $40 \mathrm{~cm}$ in length, with a opening cut $10 \mathrm{~cm}$ wide and $20 \mathrm{~cm}$ deep. There is opening at the back, possibly originally with ties as fastening. Judging from the size of the opening, it is rather close to the neck, similar to what is on this fresco Dalverzin-tepe in the 3-4th century AD (Figure 12).

\subsubsection{Neck Opening Type II (Outer Neck Facing)}

Type II is represented in A-6-6, B-3-2, D-6-2, D-9-3, E-2-1 and X-1.

A-6-6: A-6-6 is made of spun silk taquete, rather rectangular in shape, we call it outer neck facing. It is single layer with a seam allowance of $0.8 \mathrm{~cm}$ at the edge for hemming. This facing piece is made of two pieces: one labeled as A-6-6a is $35 \mathrm{~cm}$ in length and $10 \mathrm{~cm}$ in the broadest width and $6 \mathrm{~cm}$ the narrowest. The other labeled as A-6-6b is $10 \mathrm{~cm}$ in the broadest width and $6 \mathrm{~cm}$ the narrowest. Pairing the above-mentioned two pieces together, it can be inferred that the 
collar piece measures around $49 \mathrm{~cm}$ in length, with the upper part of $25 \mathrm{~cm}$ in width and the narrow bottom of $12 \mathrm{~cm}$ (Figure 13).

B-3-2: B-3-2 is an outer neck facing with the similar shape as that of A-6-6 and D-6-2, D-9-3 and E-2-1. As the upper part of the collar facing is missing, it can only be inferred from the recovery illustration of the collar that the piece should be between 55 and $60 \mathrm{~cm}$ in length and between 30 and $33 \mathrm{~cm}$ in width, the upper portion $19 \mathrm{~cm}$ wide.

At inside and outside edges of B-3-2, decorative ribbon was stitched respectively, of which the ribbon close to the inside edge was made of 2 layers sewn together. The ribbon at the outside edge is a green silk taquete decorated with pearl roundel (B-3-2a). The ribbon close to the inside edge is made of silk samite (B-3-2b) $3 \mathrm{~cm}$ in width. The dark brown silk ribbon close to the outside edge is approximately $1.5 \mathrm{~cm}$ in width (B-3-2c). (Figure 14).

Most of the neck facings measure between 50 and $60 \mathrm{~cm}$ in length, between 20 and $30 \mathrm{~cm}$ in width at the top portion, and bottom edge between 12 and $20 \mathrm{~cm}$. Figure 14 shows Type II neck opening facing is connected to the L-2 bodice in the reconstruction drawing (Figure 15), with front and back view. The back view of a trader on the stone engravings of Fujia in Qingzhou in the 6th century AD is a reference of what its back look likes on the body (Figure 16).

According to excavation of B-3-1 and B-3-2 condition, neck opening Type I and II are not stitched together. The shape of the inside edge of Type II(B-3-2) is similar to the shape of the outside edge of Type I(B-3-1). The two types may be arranged in pairs. They are probably stitched together with the collar, or Type I is part of an under-garment, and Type II should be the neck opening facing on an outer-garment. It is difficult to judge now because of the lack of the excavation information.

Based on a comparison with the textile fragments excavated from Coffin A-6, B-8, D-9, E-2 and L-2, this type of upper garment has a neck opening, and on top is the pull over garment with the neck facing, this should be the basic form of the local costume. Aside from upper garments, no trace of pants or skirts can be identified from the excavated textiles from Tomb No.5. Viewing from the top view of the excavated coffin No. A-10, there were strips of silk at the ankles of the body (Figure 17). These might be trimming of the upper garment, or of pants or skirts.. Russian scholar Sergery Yatsenko, made related studies on the costumes of Munchaktepa, suggesting there should be pants worn with the upper garments, as illustrated in Figure 18.

\subsection{Footwear}

Remains of leather goods on waist and legs below knees were disclosed in male and female burials. Definitely, they are remains of leather belt and also footwear. The footwear was, obviously, soft boots without heels and prototype of modern makhsi - massi (ichigi) of Uzbeks in the Ferghana Valley, Khorezm area, etc. The evidence of it is wooden boot-tree for footwear production. It was cut by knife out entire piece of wood; it has convex basis, obtuse toe and round-convex back reminding shape of ichigi. Reverse of foot-tree is even. It is $27.5 \mathrm{sm}$ long and $8 \mathrm{sm}$ wide, what is approximately corresponded to $42-43$ modern size. It is thoroughly polished and very slick.

An iron knife with large massive wooden handle was disclosed near foot-tree. Perhaps, besides soft boots there were different types of footwear. It is possible to judge about it according to remains of leather and ropes made of thick threads. The latter ones were used to tie footwear somehow analogue to modern boots. The soft boots - ichigi, obviously were the most fashionable type in the $5-8^{\text {th }}$ centuries in Central Asia. The soft boots - ichigi were known mainly according to murals till recent time. The analogue boots made of leather were disclosed in Sogdian site of Kafyrkala (excavated by Berdimuradov A.) and among collection of finds from Mug Mountain in Sogd and also in Tashkent oasis. In the Ferghana Valley at Karabulak Ju.D. Baruzdin disclosed boots without heels, i.e. ichigi.

Discovery in Munchaktepa let us learned about the costume of residents in the Fergana Basin in 5-6 century AD. Both men and women wearer large coat and trousers, it's similar to the costume of Sogdian population with the same period. Besides, the textile of the costume also reflects the technical exchanges with China.

\section{References}

J, Harmata. (2003). History of Civilizations of Central Asia, Beijing.

Sergey Yatsenko. (2006). Costume of the Ancient Eurasia (the Iranian-Speaking Peoples) (Kostyum drevney Evrazii [iranoyazychniye narody]). Moscow.

Zheng,Yan. (2002). Research on the Mural Tombs in the Wei-jin and Northern-southern Dynasties, Beijing.

\section{Notes}

Note 1. Matbabaev B.Kh., 1994. To the discovery of the Unique Necropolis in Northern Ferghana // New Archaeological discoveries in Asiatic Russia and Central Asia. S.Petersburg. 1994. Rr. 86-88.

Note 2. Matbabaev B. Kh., Maytdinova G.M., 1995. Tkani i odejda iz Munchaktepa // Arxeologiya i xudojestvennaya kultura Sentralnoy Azii. TD. Chast 2. Tashkent. S.40-41 
Note 3. 70. Maytdinova G., 1992. Kostyum rannesrednevekovogo Toxaristana. Istoriya i svyazi. Dushanbe. pp.66-68 Note 4. Bernshtam A.N., 1940. Kenkolskiy mogilnik // Arxeologicheskiye yekspedisii Yermitaja. Vyp. II. Leningrad. Note 5. Brykina G.A., 1982. Yugo-zapadnaya Fergana v pervoy poloviny I tysyacheletiya nashey yery. Moskva.pp126.

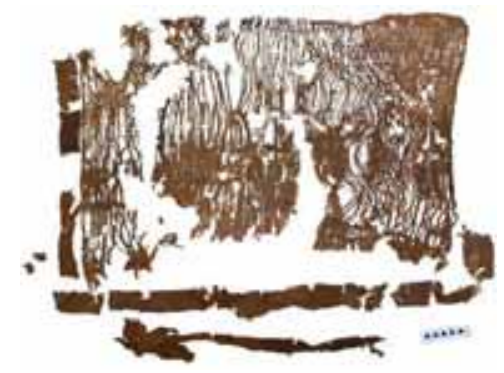

Figure 1. B-5-1

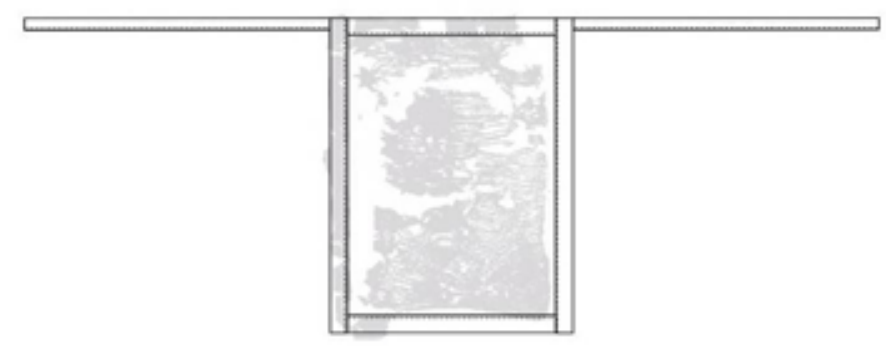

Figure 2. Reconstruction drawing of face cover

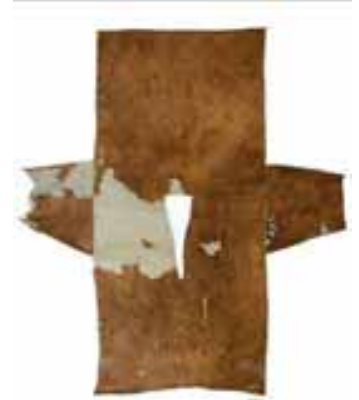

D-6-1

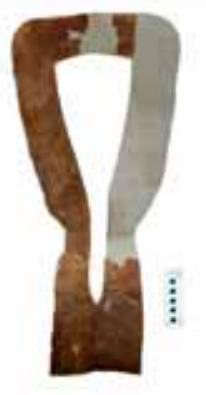

D-6-2

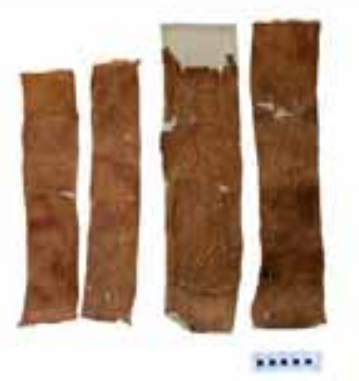

D-6-3\4\5\6

Figure 3. D-6 


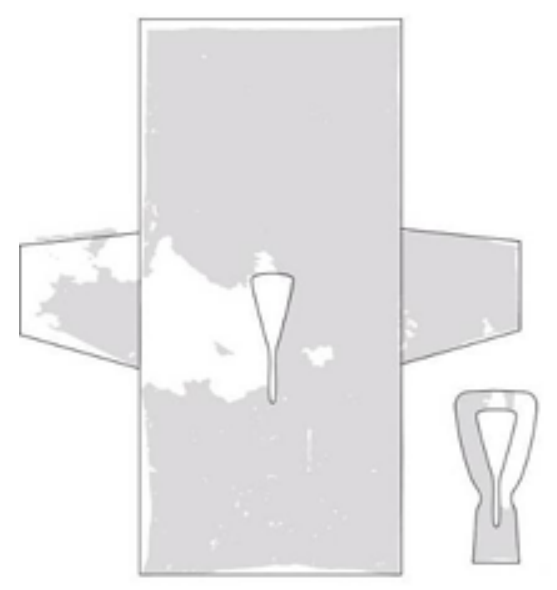

Figure 4. Reconstruction Drawing of D-6

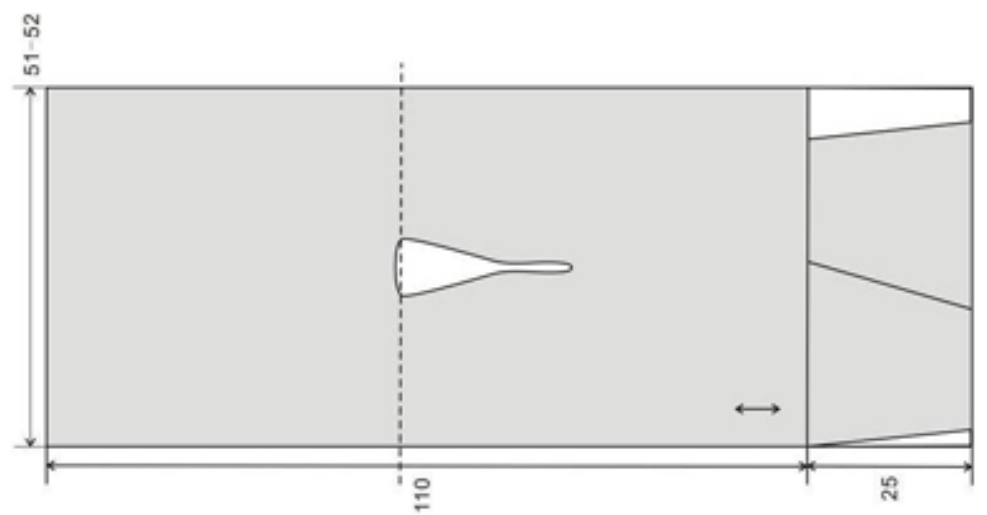

Figure 5. Cutting diagram of D-6
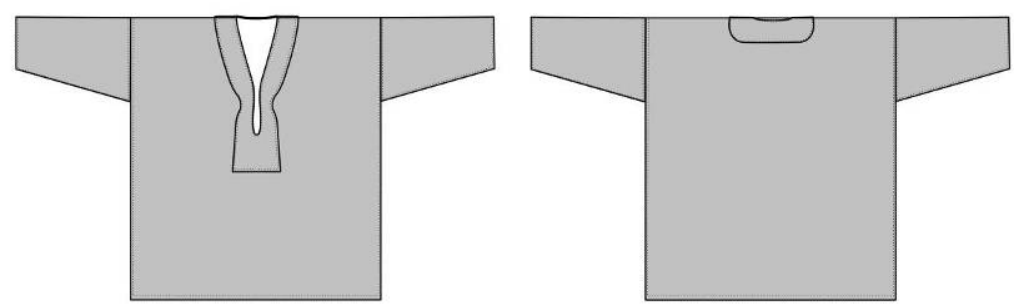

Figure 6a. Front and back view of D-6 


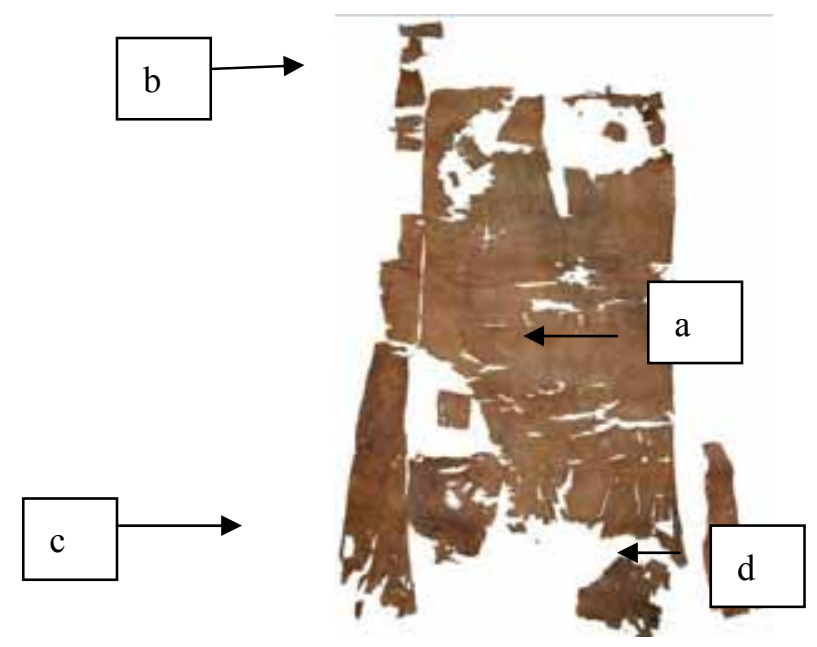

Figure 6b. L-2-1
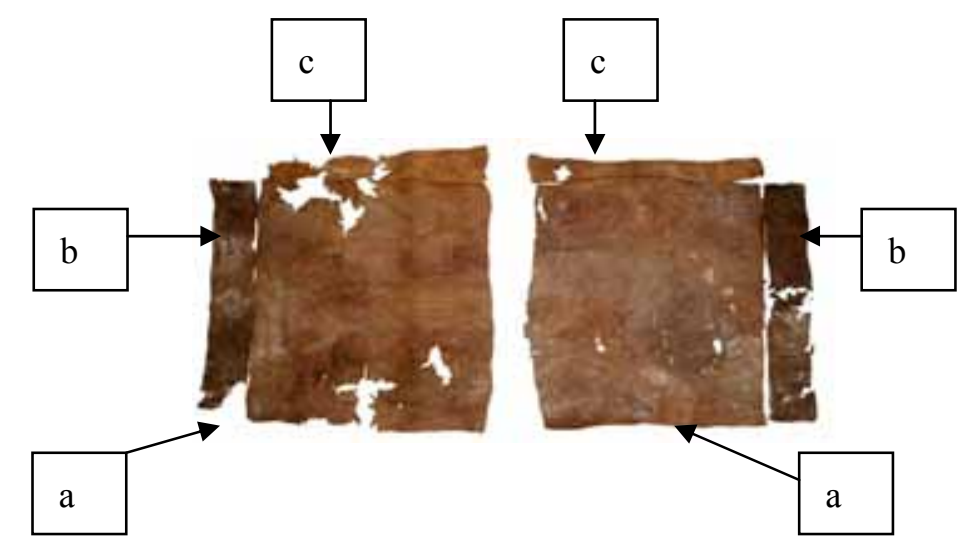

Figure 7. L-2-2

Figure 8. L-2-3

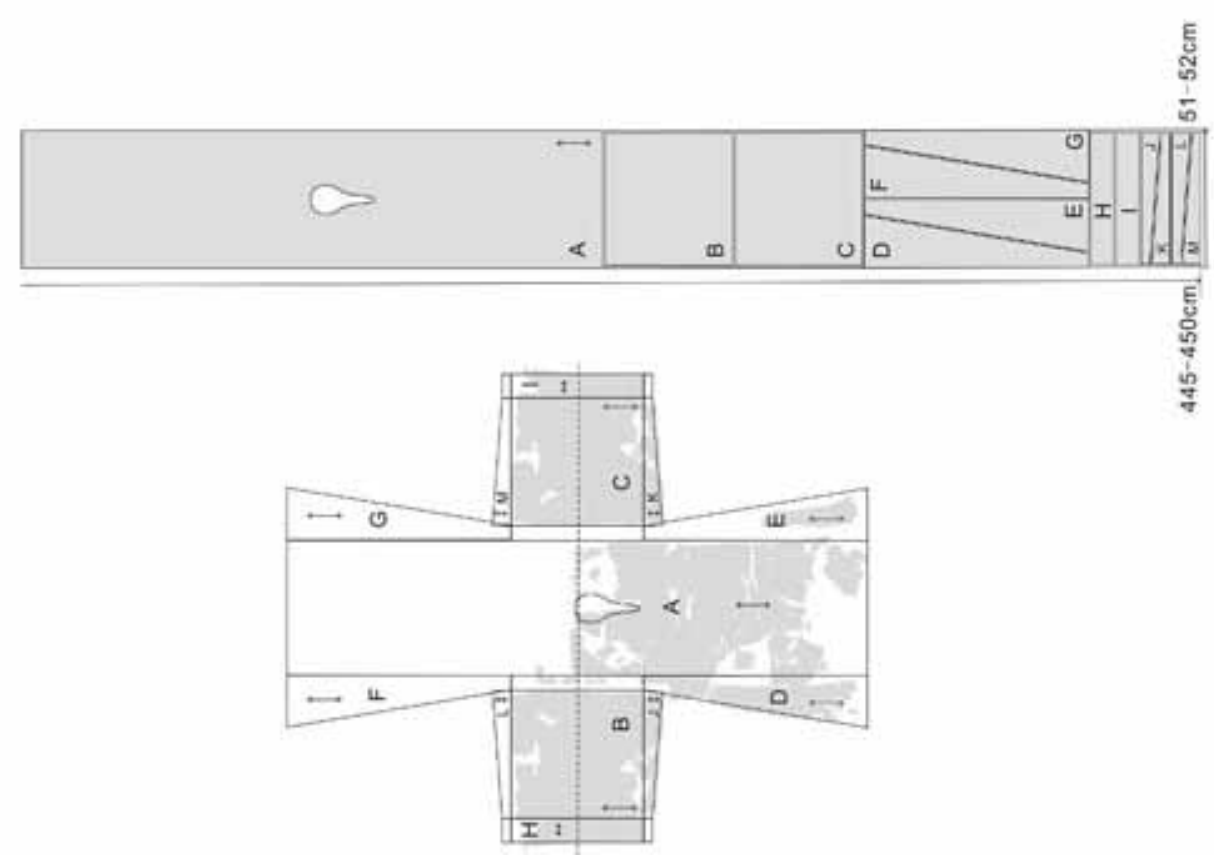

Figure 9. Cutting method of L-2 


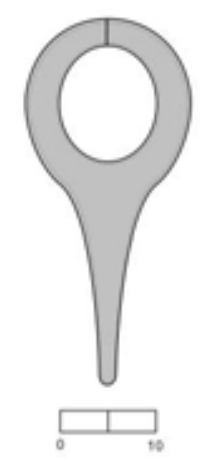

Figure 10. B-3-1

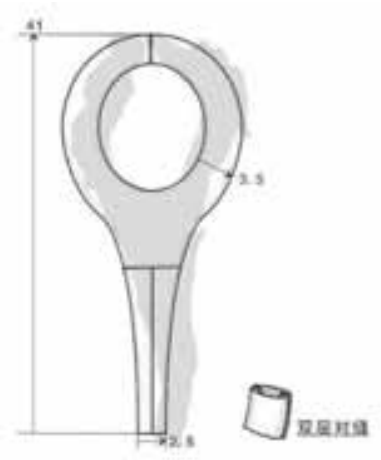

Figure 11. C-6-1

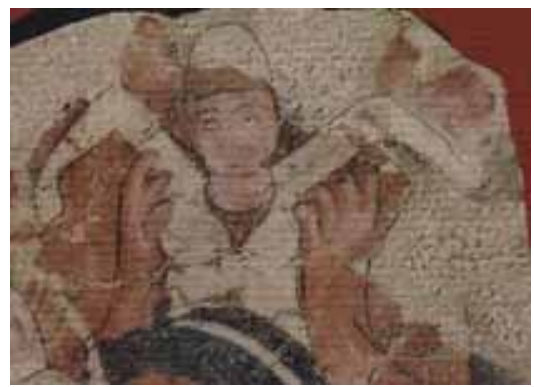

Figure 12. Wall paint of Dalverzin-tepe

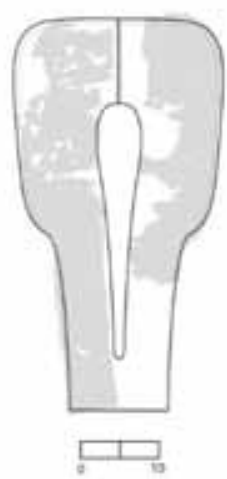

Figure 13. A-6-6 


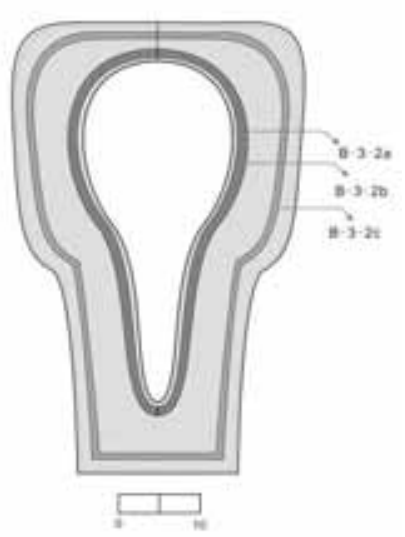

Figure 14. B-3-2
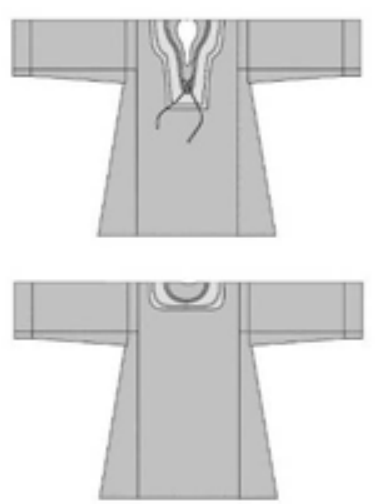

Figure 15. Reconstruction drawing of L-2

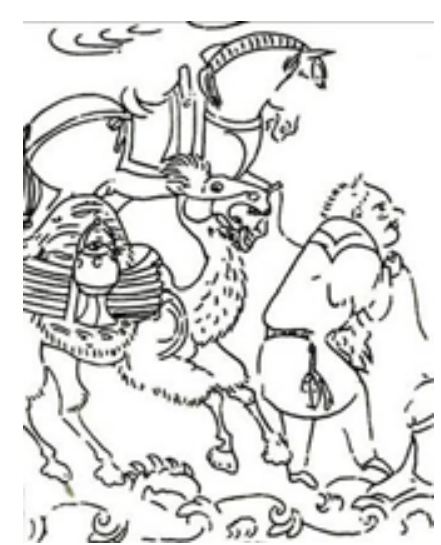

Figure 16. Stone engravings of Fujia in Qingzhou 


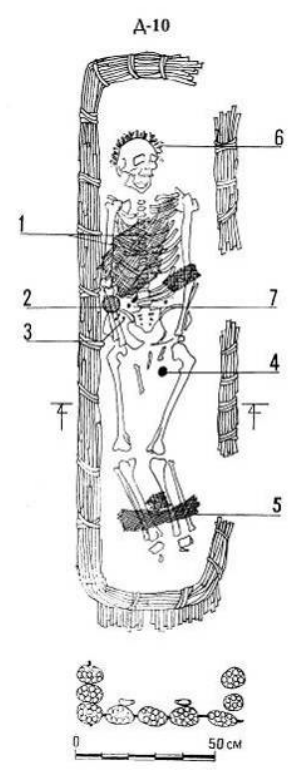

Figure 17. Top view of A-10
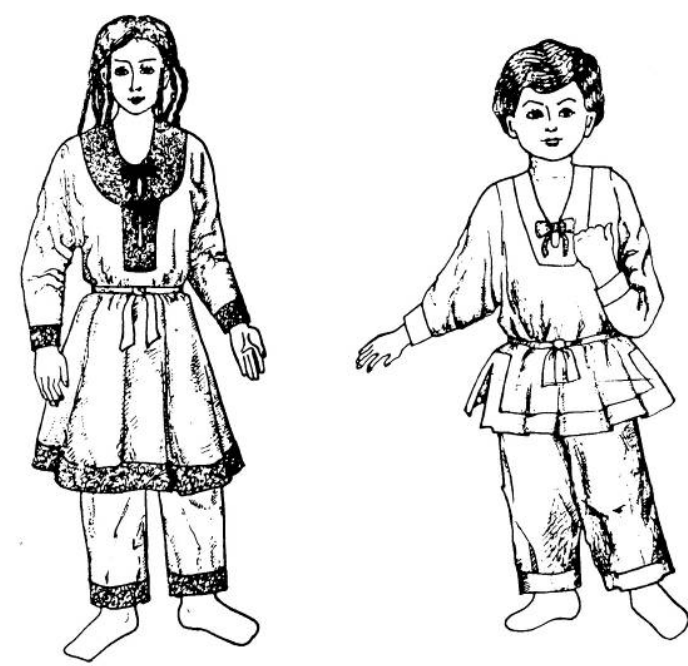

Figure 18. Drawing of female and male costume in Munchaktepa 